13 Barker DJP, ed. Fetal and infant origins of adult disease. London: British Medical Journal, 1992

14 Campbell JM, Cameron D, Jones DM. High maternal mortality in certain areas. London: HMSO, 1932. (Ministry of Health reports on public health and medical subjects No 68.)

15 Local Government Board. Thirty-ninth annual report 1909-10. Supplement on infant and child mortality. London: HMSO, 1910

16 Booth C. Life and labour of the people in London. First series: poverty. Volume 1. East, central and south London. London: MacMillan, 1902.

17 Registrar General of Births, Deaths, and Marriages in England and Wales. Supplement to the seventy fifth annual report. Pant III, registration summary tables 1901-10. London: HMSO, 1919.

18 Registrar General of Births, Deaths, and Marriages in England and Wales. Seventy fourth annual report (1911). London: HMSO, 1913.

19 Census of England and Wales 1911. Volume VII. Ages and condition as to marriage. London: HMSO, 1913.

20 Census of England and Wales 1911. Volume IX. Birthplaces. London: HMSO, 913.

21 Registrar General of Births, Deaths, and Marriages in England and Wales. Supplement to the sixty fifth annual report. Part I, registration summary tables 1891-1900. London: HMSO, 1907.
22 Booth C. Life and labour of the people in London. First series: poverty in London. Volume 3. Blocks of buildings, schools and immigration. London: MacMillan, 1902.

23 Booth C. Life and labour of the people in London. Second series: industry. Volume 5. Comparisons, survey and conclusions. London: MacMillan, 1903.

24 Lumey LH. Decreased birthweights in infants after maternal in utero exposure to the Dutch famine of 1944-1945. Pediatric and Perinatal Epidemiology 1992;6:240-53

25 Ariouat J, Barker DJP. The dici of girls and young women at the beginning of the century, Nutrition and Health (in press).

26 Booth C. Life and labour of the people in London. Second series: industry in London. Volume 4. Public professional and domestic service, unsuccessful classes. London: MacMillan, 1903.

27 The new survey of London life and labour. Volume II. London industries. London: P S King and Son, 1931.

28 London County Council. Annual report of council 1915-19. Volume III, public health. London: LCC, 1919.

29 Wall R. Some inequalities in the raising of boys and girls in nineteenth and twentieth century England and Wales. Cambridge: Cambridge Group for the History of Population and Social Structure, 1990.

\title{
Socioeconomic differentials in mortality: evidence from Glasgow graveyards
}

\author{
George Davey Smith, Douglas Carroll, Sandra Rankin, David Rowan
}

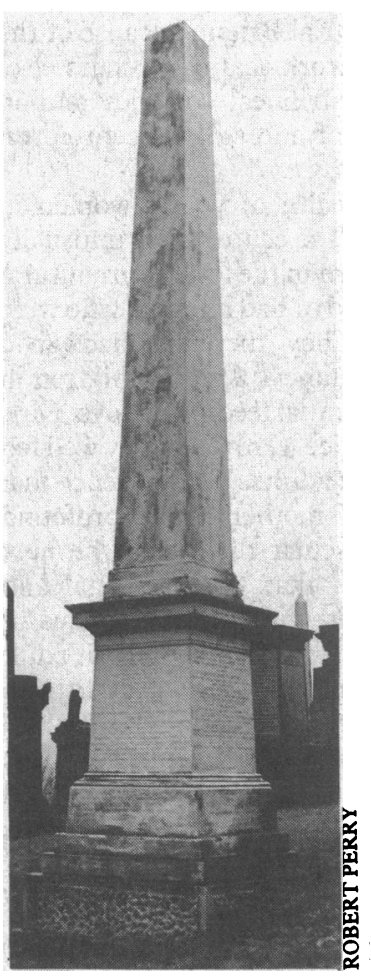

Department of Public Health, University of Glasgow, Glasgow G12 8RZ

George Davey Smith, senior lecturer in public health and epidemiology

Department of Psychology, Glasgow Polytechnic, Glasgow G4 0BA

Douglas Carroll, professor Sandra Rankin, research associate

David Rowan, research associate

Correspondence to: Dr Davey Smith.

BMF 1992;305:1554-7

\section{Introduction}

In 1842 the average age of death for "gentlemen and persons engaged in the professions and their families" was 45 years, for "tradesmen and their families" it was 26 years, whereas for "mechanics, servants and labourers and their families" it was only 16 years. ${ }^{1}$ In 1904 , the report of the interdepartmental committee on physical deterioration noted the paucity of data available on social status and mortality, commenting in particular on the failure of the registrar general's routine statistical returns in this regard. ${ }^{2}$ Responding in part to this demand, T H C Stevenson, one time superintendent of statistics at the General Register Office, analysed mortality for the years 1910-2 according to eight occupationally based social class groups. ${ }^{3}$ He noted that this was unsatisfactory, since it was too dependent on classifications according to industry, with "all grades of worker, master and man, skilled and unskilled" grouped together in some cases. In 1921 "a determined attempt was made to purge the occupational classification of its industrial taint," it is from the reports of social class differentials in mortality around the 1921 census $^{4}$ that the continuing series of decennial supplements on occupational mortality are generally dated.'

Since 1921 these reports have revealed a more or less consistent pattern of risk in all cause mortality increasing from the professional groups in social class I to the unskilled labourers in social class V. ${ }^{4-10}$ More recent studies focusing on non-occupational measures of material wellbeing, such as housing tenure and car ownership, have generally been able to differentiate mortality risk better than analysis by social class alone. ${ }^{11}$ Indices such as these are not recorded on death certificates, so mortality rates cannot be computed by comparing death registrations (numerator) to census figures for the population at risk (denominator). Showing large differentials in mortality according to asset based measures of available income has therefore depended on following up large cohorts ${ }^{12} 1^{13}-$ but such data cannot be obtained for earlier periods.

One way the issue can be explored is through commemorative obelisks of a uniform design (figure) found in burial grounds in Glasgow. The height of these obelisks varies greatly, yet their shape remains standard. As the height would influence the cost of the obelisk, it is reasonable to assume that more wealthy decedents would be commemorated by taller obelisks. We set out to determine whether better socioeconomic status, indexed by taller obelisks, was associated with greater longevity during the period 1801-1920.

\section{Method}

A standard form of obelisk is a common marker of graves in the graveyards of Glasgow. All such obelisks were inspected in eight graveyards in Glasgow: the Cathedral, Eastern, Southern, and Western Necropolises, and Sighthill, Vennel, Rutherglen, and Craigton graveyards. From the obelisk, details were taken of the year of death and age at death of the first generation of the family commemorated by the obelisk. In general the obelisk would have been erected in memory of the first deceased of these; their year of death was taken to be the year of construction of the obelisk. Some obelisks commemorated only a male or female family elder; from these only one set of data were recorded. Only people dying before 1921 were included in this study as the registrar general started reporting death rates by five social class groups for the period around the 1921 census. If one of a couple commemorated on an obelisk died before 1921 and one after, only data for the former were used.

If data were incomplete - on some obelisks the date of death, but not age at death, was recorded - a record of the burial was consulted. ${ }^{14}$ Even so, complete data could not be obtained for 60 people. The inscriptions were illegible on 95 obelisks, usually because of weathering, although some could not be read because they had collapsed with the inscription facing downwards and could not be turned over.

The height of each obelisk was measured with a set of chimney sweep rods, each $90 \mathrm{~cm}$ long, with gradations added. Height was measured from the base of the plinth to the crest of the pyramidal top piece, to the nearest $5 \mathrm{~cm}$. The principal material in the obelisk - granite, marble, or sandstone - was recorded. Four obelisks made of different materials (three iron, one concrete) were not included in the study. Granite was, and is, the most expensive of these materials and sandstone the least expensive ( $R$ Taylor, personal communication). ${ }^{15}$ The price differential between the materials depends on the exact source of the material and has varied over time, so no precise quantification of costs can be made. Therefore the three materials have been simply treated as giving an ordering of the cost for each obelisk at any given height.

The relations between continuous variables were 


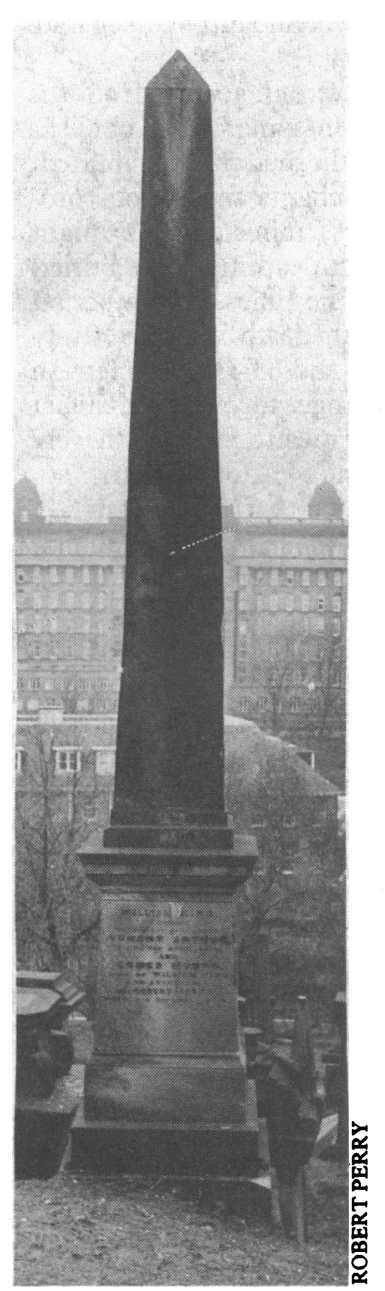

TABLE I-Period of construction of obelisks

\begin{tabular}{lr}
\hline & No (\%) built \\
\hline $1801-1820$ & $7(1)$ \\
$1821-1840$ & $20(2)$ \\
$1841-1860$ & $94(11)$ \\
$1861-1880$ & $267(32)$ \\
$1881-1900$ & $282(33)$ \\
$1901-1920$ & $173(21)$ \\
\hline
\end{tabular}

examined by correlation and linear regression analyses. Differences in means were examined through analysis of variance and difference in medians by the MannWhitney U test.

\section{Results}

Data were obtained from 843 obelisks, 264 from the Cathedral Necropolis, 191 from Sighthill graveyard, and 388 from the six other graveyards combined. The earliest obelisk was constructed in 1805, and the median year of construction was 1883 . Table I presents the number and proportion of obelisks built during 20 year periods from 1801 to 1920.

Height of the obelisks ranged from $1: 75 \mathrm{~m}$ to $11.40 \mathrm{~m}$, with a mean (SD) of $3.91(1.11) \mathrm{m}$. Granite was the principal material for $514(61 \%)$ of the obelisks, marble for $171(20 \%)$, and sandstone for $158(19 \%)$. The median year of construction of the sandstone obelisks was 1873, earlier than the median of 1884 for the granite ones, which in turn is earlier than 1890 for the marble ones (all differences $p<0.01$ by Mann-Whitney $U$ test). The mean heights of the three types of obelisk $(3.89 \mathrm{~m}$ for granite, $3.91 \mathrm{~m}$ for marble, and $3.98 \mathrm{~m}$ for sandstone) are similar $(\mathrm{p}=0.7$ by analysis of variance).

The 843 obelisks yielded data for 725 men and 624 women dying before 1921 . The median year of death of these 1349 people was 1889 . The mean ages at death are presented according to year of death and sex in table II (range 20-98). Men had a higher mean age of death than women during all but the most recent time period. After 1860 there is a steady increase in mean age at death. If deaths occurring during the main childbearing years are excluded, a female advantage emerges earlier and is more pronounced (table III).

Correlations between height of obelisk, age at death, and year of death are presented in table IV. As shown in table II, age at death increased over the time period. The average height of the obelisks decreased with year of death, but increased with age at death. Table V presents age at death according to tertile of the height of the obelisks, together with the coefficient from simple linear regression of age at death against height of obelisk. The regression analyses show that every metre in height of obelisk translates into 1.42 years later age at death ( $95 \%$ confidence interval 0.53 to $2 \cdot 31$ ) for men and $2 \cdot 19(0.93$ to 3.45$)$ for women.

The average height of obelisks fell over time, whereas mean age at death increased. Correlations between height of obelisk and age at death are presented for different time periods in table VI. These are generally higher than the overall correlations. Multiple regression was performed, with age at death as the dependent variable and height of obelisk and year of death as the independent variables. These analyses reveal that, adjusted for year of death, each

TABLE II-Age at death (years)

\begin{tabular}{lrcrrr}
\hline & \multicolumn{2}{c}{ Males } & & \multicolumn{2}{c}{ Females } \\
\cline { 2 - 3 } \cline { 5 - 6 } & No & Mean age & & No & Mean age \\
\hline $1801-1860$ & 89 & $59 \cdot 7$ & & 57 & $53 \cdot 4$ \\
$1861-1880$ & 194 & $57 \cdot 5$ & & 147 & $52 \cdot 6$ \\
$1881-1900$ & 252 & $65 \cdot 4$ & & 234 & $63 \cdot 6$ \\
$1901-1920$ & 190 & 67.5 & & 186 & $70 \cdot 2$
\end{tabular}

TABLE III-Mean age at death of men and women aged over 45 years

\begin{tabular}{lrcrrr}
\hline & \multicolumn{2}{c}{ Males } & & \multicolumn{2}{c}{ Females } \\
\cline { 2 - 3 } \cline { 5 - 6 } \cline { 5 - 6 } & No & Mean age & & No & Mean age \\
\hline $1801-1860$ & 71 & $65 \cdot 1$ & & 37 & $62 \cdot 5$ \\
$1861-1880$ & 153 & $63 \cdot 0$ & & 90 & $64 \cdot 0$ \\
$1881-1900$ & 234 & $67 \cdot 4$ & & 201 & $68 \cdot 5$ \\
$1901-1920$ & 184 & $68 \cdot 5$ & & 171 & $73 \cdot 2$ \\
\hline
\end{tabular}

TABLE IV-Correlations between height of obelisk, age at death, and year of death (men above diagonal, women below diagonal)

\begin{tabular}{lccr}
\hline & $\begin{array}{c}\text { Age at } \\
\text { death }\end{array}$ & $\begin{array}{c}\text { Year of } \\
\text { death }\end{array}$ & $\begin{array}{c}\text { Height of } \\
\text { obelisk }\end{array}$ \\
\hline $\begin{array}{l}\text { Age at death } \\
\text { Year of death }\end{array}$ & $0 \cdot 25^{\star \star}$ & $\begin{array}{r}0 \cdot 12^{\star \star} \\
-0 \cdot 15^{\star \star}\end{array}$ \\
\hline Height of obelisk & $0 \cdot 40^{\star \star}$ & $-0 \cdot 11^{\star}$ & \\
\hline
\end{tabular}

${ }^{\star} \mathrm{p}<0.01 .{ }^{\star \star} \mathrm{p}<0.005$.

TABLE V-Age of death according to height of obelisk

\begin{tabular}{lcccc}
\hline & & \multicolumn{2}{c}{ Age at death } \\
\cline { 3 - 5 } & \begin{tabular}{c} 
Mean \\
\cline { 3 - 5 }
\end{tabular} & $2 \cdot 99$ & $61 \cdot 6$ & $58 \cdot 3$ \\
\hline Lowest third & $3 \cdot 77$ & $62 \cdot 8$ & $63 \cdot 1$ \\
Middle third & $5 \cdot 10$ & $64 \cdot 8$ & $65 \cdot 1$ \\
Highest third & & $1 \cdot 42^{\star}$ & $2 \cdot 19^{\star}$ \\
Regression coefficient per metre height & & & Men & Women \\
& & &
\end{tabular}

${ }^{\star} \mathrm{p}<0.005$.

TABLE VI - Mean age at death related to height of obelisks

TABLE VII - Mean age at death according to material of obelisk

\begin{tabular}{|c|c|c|c|c|c|}
\hline & Males & Females & & Males & Females \\
\hline $\begin{array}{l}1801-1860 \\
1861-1880 \\
1881-1900 \\
1901-1920\end{array}$ & $\begin{array}{l}0 \cdot 34^{\star \star} \\
0 \cdot 15^{\star} \\
0 \cdot 16^{\star} \\
0 \cdot 07^{\star}\end{array}$ & $\begin{array}{l}0 \cdot 15 \\
0 \cdot 23^{\star \star} \\
0 \cdot 12 \\
0 \cdot 28^{\star \star}\end{array}$ & $\begin{array}{l}\text { Granite } \\
\text { Marble } \\
\text { Sandstone }\end{array}$ & $\begin{array}{l}63 \cdot 7 \\
63 \cdot 5 \\
60 \cdot 9\end{array}$ & $\begin{array}{l}62 \cdot 6 \\
61 \cdot 3 \\
61 \cdot 3\end{array}$ \\
\hline
\end{tabular}

${ }^{\star} \mathrm{p}<0.05 .{ }^{\star \star} \mathrm{p}<0.005$.

TABLE VIII - Analyses for the two major burial grounds

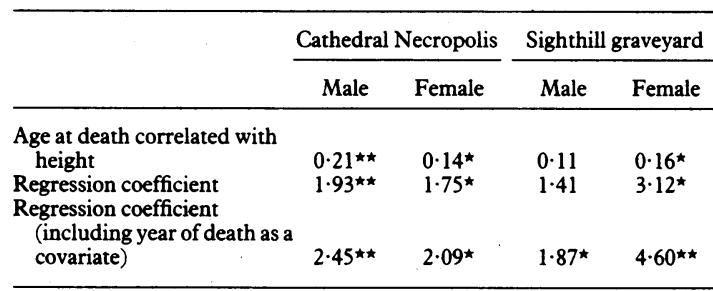

${ }^{\star} \mathrm{p}<0.05 .{ }^{\star \star} \mathrm{p}<0.005$.

metre in height of obelisk translates into 1.93 (1.06 to $2 \cdot 80$ ) years later age at death for men and an equivalent value of 2.92 ( 1.76 to 4.08 ) years for women.

The mean ages at death according to the material of the obelisk are presented in table VII. The trend is in the expected direction - that is, higher mean age at death correlates with the more expensive materialsbut the effect is weak and not significant at conventional levels for either men (analysis of variance $p=0 \cdot 1$; as trend in regression analysis $\mathrm{p}=0.06$ ) or women (analysis of variance $\mathrm{p}=\mathbf{0 . 7}$; as trend in regression analysis $\mathrm{p}=0 \cdot 4$ ).

The main analyses were repeated separately for the two largest graveyards, which supplied $54 \%$ of obelisks in this study. As shown in table VIII, the pattern of

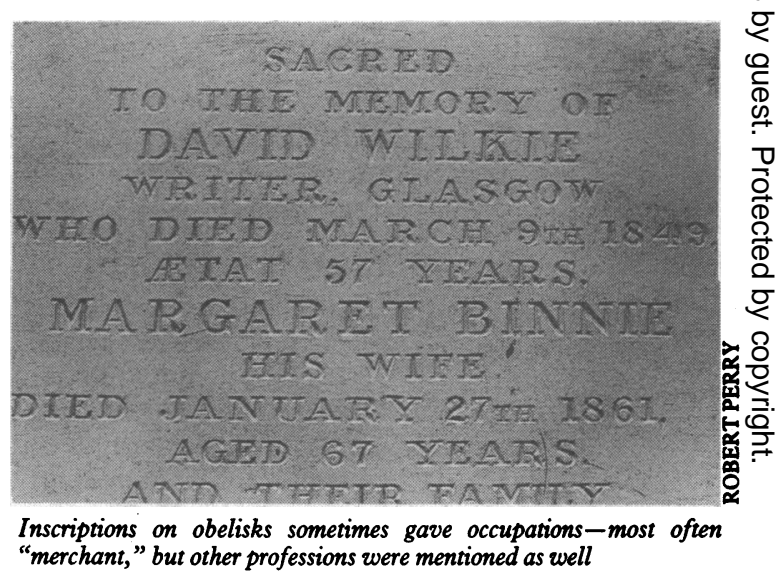
Inscriptions on obelisks sometimes gave occupations-most often
"merchant," but other professions were mentioned as well 


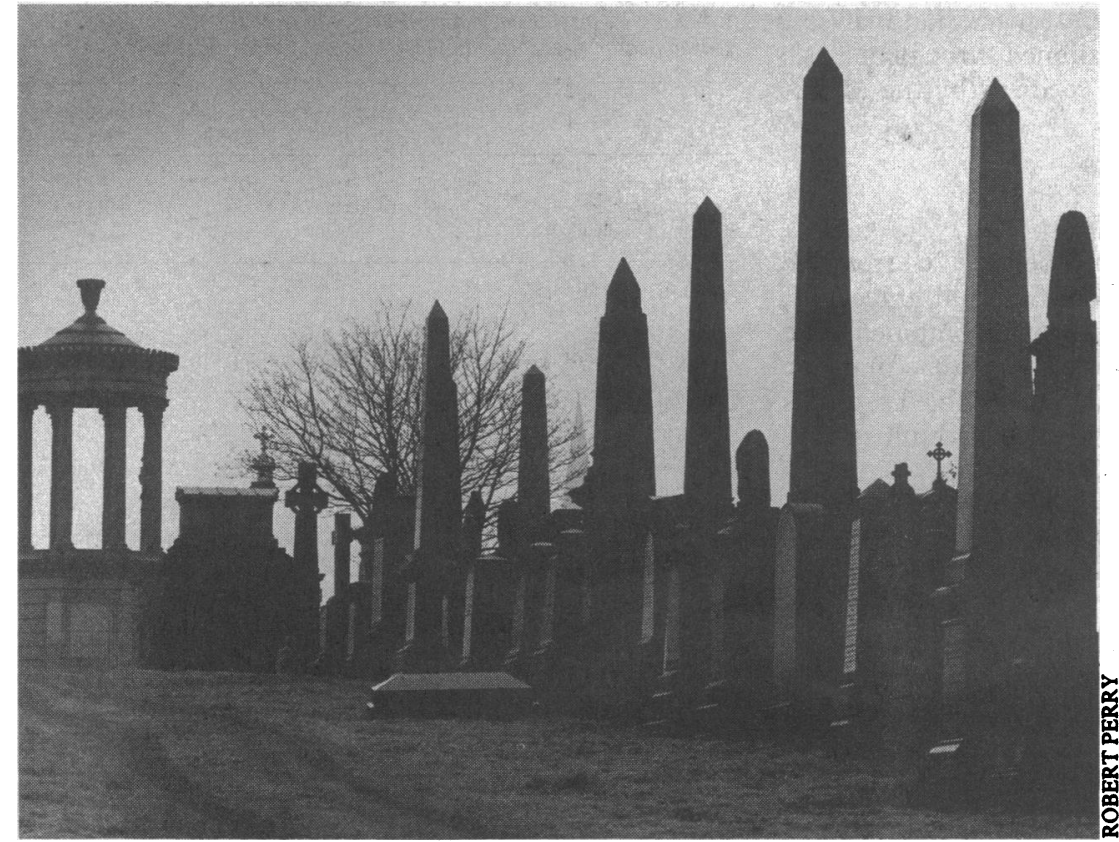

Obelisks were part of the

Egyptian imagery so popular in

Victorian graveyards

results which emerged from these analyses was much the same as in the whole sample.

\section{Discussion}

We used the average age at death as the indicator of mortality risk, as it was in the 1840 s and is currently, ${ }^{16}$ because denominator data are not available. This index is sensitive to the age structure of the population. Even with internal comparisons and with analyses in which year of death is controlled, as in the present study, different age distributions for adults in different socioeconomic groups could be due to factors other than differential survival. When mortality differences between regions of Scotland at this time ${ }^{17}$ are considered both in terms of average age at death and death rates in given age categories, similar differentials are seen despite large differences in age distribution. When numerator and denominator data are not available the average age at death can be a useful index, although it must be interpreted carefully. ${ }^{16}$

With this caveat in mind, we can consider reasons for height of obelisk being associated with age at death for people buried in the main graveyards of Glasgow. It is likely that one of two processes is involved-either higher socioeconomic status, as indexed by height of obelisk, is associated with greater longevity, or living longer leads to greater accumulation of assets, which are in part exchanged for a larger memorial after death. If the latter were the case, it would be expected that the height of obelisks would be more strongly related to men's than women's age at death, since for the middle class groups who were commemorated in this manner, few women would have been independent wage earners. ${ }^{18}$ If anything, however, the association between obelisk height and age at death was greater for women than men.

It is a commonplace that Victorian society was obsessed with class. A historian of the period describes the "multiple gradations or ranks in a pyramidal order" but sees a crucial distinction between the respectable and the non-respectable. ${ }^{18}$ Burial arrangements could clearly reflect respectability and social aspirations as well as economic position. In this respect height of obelisks is no different from registrar general's social class, which is based on the notion of the general standing of an occupation within the community rather than on economic rewards of particular jobs or a theoretical understanding of the class structure. The present data do not allow us confidently to separate social display from ability to pay.

The subjects of this study were in general from the privileged strata of society. On some of the obelisks occupations were recorded for the men commemorated, who were predominantly merchants and various professionals-engineers, doctors, ministers. As might be expected, the average age at death for those buried in these grounds was old for the times. In the period 1881-1900 the mean ages at death for the study population were 65.4 for men and 63.3 for women. In $1890,{ }^{17}$. the midpoint of this range, for people dying at 20 years or over in Glasgow the mean ages at death were calculated to be $50 \cdot 1$ for men and $52 \cdot 4$ for women.

Although in 1815 Milne stated that "There can ... be no doubt but that the mortality is greater among the higher than the middle class of society," 19 the scattered evidence available suggests that in the nineteenth century there was apparently a graded relation, such that lower occupational standing was associated with higher mortality risk. ${ }^{2021}$ An exception is sometimes made for members of the peerage, who some observers thought had lower life expectancy than the general population..$^{19}$ If this were the case, then it seems to be a specific property of the aristocracy, rather than showing that the relation between socioeconomic status and mortality does not exist outside of the truly poor.

This study suggests that socioeconomic differentials in mortality existed for the relatively well off during an earlier era. Absolute poverty, as discussed by Chadwick ${ }^{1}$ and Booth, ${ }^{22}$ presumably played no part in generating the differentials reported here. Although a continuous gradation of mortality risk accompanying the fine stratification of British society is seen currently, ${ }^{23}{ }^{24}$ for earlier periods more attention is generally paid to notions of absolute impoverishment. In Glasgow, James Burn Russell, who served as the city's first full time medical officer of health from 1872 to 1898, wrote numerous reports for the Glasgow Medical fournal and the Sanitary fournal for Scotland with titles such as "Local vices of buildings as affecting the death rate" and "Public health and pauperism." Showing that mortality differentials persisted into privileged groups presents the same challenge for the interpretation of the factors underlying health inequalities then as it does now. ${ }^{26}$

A few other studies have examined the relation between non-occupational indicators of material wellbeing and mortality risk during an earlier age for which routine data are not available. Records of dowry investments made at birth for daughters of relatively affluent families in Florence from 1425 to 1442 have been related to ages at death for the girls concerned. ${ }^{27} \mathrm{~A}$ gradient of decreasing mortality risk was seen from those accompanied by a dowry of less than 49 florins to those with dowries greater than 100 florins. In Providence, Rhode Island, mortality for taxpayers and non-taxpayers in 1865 could be calculated. Less than a quarter of the population were tax payers, who constituted the affluent section of Providence society. In most age groups, death rates for nontaxpayers were two to three times higher than for taxpayers. ${ }^{28}$

Studies such as these help document the existence of socioeconomic differentials in mortality risk. The existence of such differentials among privileged groups suggests that notions of absolute poverty do not, on their own, provide an adequate explanatory framework. Further, the existence of the usual mortality gradient at a time when the familiar triad of sinsloth, smoking, and fatty food-may well have been a characteristic more of the rich than of the poor emphasises the parochial nature of explanations in terms of health related behaviours, as does the exist- 
ence now of such differentials in societies with very different social structures to those of Britain today. When Chapin documented mortality differentials in Providence in 1924 he hoped that such a demonstration would be preparation for "what should be of great value, namely a study of the habits of life and environment which make for the longevity of the well-to-do." ${ }^{28}$ This still pertains.

The authors acknowledge the generous assistance of David Crawshaw, cemeteries and crematoria officer and registrar, Glasgow City Council, and the technical support of David Bell and Moira Willison of Glasgow Polytechnic.

1 Chadwick E. Report on the sanitary condition of the labouring population of Grea Britain, 1842. Edinburgh: Edinburgh University Press, 1965.

2 Inter-Departmental Committee on Physical Deterioration. Report. London: HMSO, 1904

3 Stevenson THC. The social distribution of mortality from different causes in England and Wales, 1910-12. Biometrika 1923;15:382-400.

4 Stevenson THC. The vital statistics of wealth and poverty. Fournal of the Royal Statistical Society 1928;91:207-20.

5 Pamuk ER. Social class inequality in mortality from 1921 to 1972 in England and Wales. Population Studies 1985;39:17-31.

6 Stocks $P$. The effects of occupation and of its accompanying environment on mortality. Fournal of the Royal Statistical Society 1938;101:669-708.

Logan WPD. Social class variations in mortality. $\mathrm{Br} f$ Prev Soc Med 1954;8:128-37.

8 Hart JT. Data on occupational mortality, 1959-63: too little and too late. Lancet 1972;i:192-3.

9 Morris JN. Social inequalities undiminished. Lancet 1979;i:87-90.
10 Blane D, Davey Smith G, Bartley M. Social class differences in years of potential life lost: size, trends and principal causes. BMF 1990;301:429-32.

11 Davey Smith G, Bartley M, Blane D. The Black report on socioeconomic Davey Smith G, Bartley M, Blane D. The Black report
inequalities in health: 10 years on. BMF 1990;301:373-7.

inequalities in health: 10 years on. BMF 1990;301:373-7.
12 Fox J, Goldblatt PO. Longitudinal study: socio-demographic mortality differentials. London: HMSO, 1982.

13 Davey Smith G, Shipley MJ, Ruse G. The magnitude and causes of socioeconomic differentials in mortality: further evidence from the Whitehall economic differentials in mortality: further evidence
study. $\mathcal{F}$ Epidemiol Community Health 1990;44:265-70.

14 Willing JA, Fairie JS. Burial grounds of Glasgow: a brief guide for genealogists. Glasgow: Glasgow and West of Scotland Family History Society, 1986.

15 Spon's architects' and builders' price book. London: Spon, 1990.

16 Jannerfeldt E, Horte L-G. Median age at death as an indicator of premature mortality. BMF 1986;296:678-81.

17 Thirty-sixth detailed annual report of the Registrar-General of births, deaths and marriages in Scotland. Edinburgh: HMSO, 1892.

18 Best G. Mid-Victorian Britain 1851-1875. London: Fontana, 1979.

19 Titmuss R. Birth, poverty and wealth. London: Hamish Hamilton Medical Books, 1943.

20 Morris JN. Uses of epidemiology. London: Livingstone, 1957.

21 Antonovsky A. Social class, life expectancy and overall mortality. Milbank Memorial Fund Quarterly 1967;45:31-73.

22 Booth C. Charles Booth's London: a portrait of the poor at the turn of the century. London: Hutchinson, 1969.

23 Moser K, Pugh H, Goldblatt P. Mortality and the social classification of women. In: Goldblatt P, ed. Longitudinal study: mortality and social organisation. London: HMSO,

24 Goldblatt P. Mortality and alternative social classifications. In: Longitudinal study: mortality and social organisation. London: HMSO, 1990:163-92.

25 Checkland O, Lamb M, eds. Bibliography. In: Health care as social history: the Glasgow case. Aberdeen: Aberdeen University Press, 1982.

26 Davey Smith G, Egger M. Socioeconomic differences in mortality in Britain and the United States. Am f Public Health 1992;82:1079-81.

27 Morrison AS, Kirshner J, Molho A. Life cycle events in 15th century Florence: records of the Monte Delle Doti. Am J Epidemiol 1977;106: 487-92.

28 Chapin CV. Deaths among taxpayers and non-taxpayers of income tax, Providence, 1865. Am F Public Health 1924;14:647-51.

\section{The transformation of maternal mortality}

\section{Irvine Loudon}

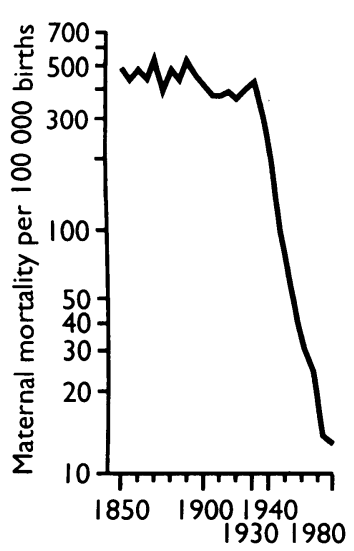

FIG 1-Maternal mortality, quinquennial averages 1850-1980. Logarithmic scale

Wantage, Oxfordshire OX12 9EH

Irvine Loudon, medical historian

BMf 1992;305:1557-60
There can be no doubt that the most remarkable feature of childbirth in this century is the profound decline in maternal deaths throughout the Western world. From 1900 to 1935 the average maternal mortality in England and Wales was around 400 per 100000 births, with the lowest rate of 355 in 1910 and the highest, 441, in 1934. From 1935, however, there was a dramatic change. Maternal mortality began its steep and sustained decline until, by the 1980 s, it had fallen to less than nine deaths per 100000 births: roughly one fiftieth of the rate in $1934 .^{1}$

Figure 1 shows these features: the plateau of maternal mortality followed by the steep and continuous fall. A broadly similar trend-a plateau and a steep decline-was seen in all Western countries. During the period from 1900 to 1935 , however, there were striking differences in national levels of maternal

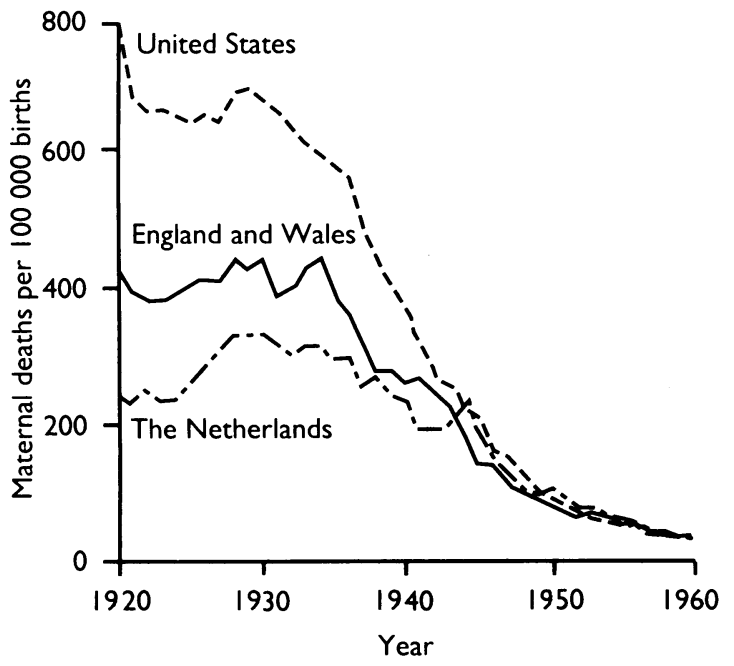

FIG 2-Annual trends in maternal mortality expressed as maternal deaths per 100000 births mortality (table I, figure 2). The United States had the highest level of maternal mortality, the Netherlands and Scandinavia the lowest; England and Wales occupied an intermediate position. Only a small part of international differences could be attributed to statistical methodology. When these were eliminated, the rank order shown in table I remained intact.

TABLE I-Maternal mortality in certain countries in $1920 .{ }^{25}$

\begin{tabular}{lc}
\hline Country & $\begin{array}{c}\text { Maternal mortality from all } \\
\text { causes (per 100 000 live births) }\end{array}$ \\
\hline Denmark & 235 \\
The Netherlands & 242 \\
Sweden & 258 \\
Norway & 297 \\
Finland & 360 \\
England and Wales & 433 \\
Australia & 501 \\
Ireland & 553 \\
Belgium & 609 \\
Scotland & 615 \\
New Zealand & 648 \\
France & 664 \\
United States & 689
\end{tabular}

$\star 1918 .+1919$.

Why were there such wide differences between Western countries? Why was it so much safer in the 1920s to have a baby in the Netherlands than the United States? And why, as we will see, had these wide differences virtually disappeared by 1960 ? It might be thought that the answer lay in social and economic differences, on the assumption that rates of maternal mortality were primarily determined by factors such as poverty and malnutrition - but this was not the answer. Maternal mortality, unlike infant mortality, was remarkably insensitive to social and economic factors per se but remarkably sensitive to standards of obstetric care. ${ }^{34} \mathrm{I}$ believe that the answers to the questions asked above will be found in international comparisons of maternal policies and systems of maternal care. I have 